INVENTORY:Jurnal Akuntansi

ISSN 2597-7202 (Print); ISSN 2613-912X (Online)

Vol. 5, No. 2, Oktober 2021, Hal 135-143

Tersedia Online: http://e-journal.unipma.ac.id/index.php/inventory

\title{
Analisis Sistem Akuntansi Persediaan Bahan Baku Dalam Mengendalikan Persediaan
}

\author{
Pitriyani $^{1}$, Evi Martaseli ${ }^{2 *}$, Tina Kartini ${ }^{3}$ \\ Progam Studi Akuntansi, Universitas Muhammadiyah,Sukabumi, Indonesia \\ Email : fitriyani220@gmail.com¹; evimartaseli@yahoo.com²; \\ tinakartini386@ummi.ac.id ${ }^{3}$
}

\begin{abstract}
Abstrak
Tujuan dilakukannya penelitian ini adalah untuk mengetahui dan menjelaskan metode pencatatan persediaan, penerapan sistem akuntansi persediaan bahan baku, dan pengendalian persediaan yang dilakukan pada PT. YYY. Dalam penelitian ini data yang diperoleh oleh peneliti menggunakan metode deskriptif kualitatif. Penelitian ini menggunakan data primer dan data sekunder dimana data dilaksanakan dengan penelitian langsung ke lapangan dan juga menggunakan studi kepustakaan.Hasil dari analisis menunjukan bahwa tidak ditemukan adanya perbedaan mengenai metode yang digunakan oleh perusahaan dengan teori, unit pengendalian sudah sesuai teori dan tidak ditemukan adanya perbedaan mengenai penerapan sistem dan prosedur yang terkait dengan sistem akuntansi persediaan dan fungsi-fungsi yang terkait dalam persediaan bahan baku yang ada sudah sesuai teori dan ada tambahan fungsi lainnya yaitu fungsi gudang, produksi, pengiriman dan pembelian. Namun adanya perangkapan fungsi dan sering terjadi mutasi barang tanpa dokumen pendukung dan hanya menggunakan lisan pada PT. YYY.
\end{abstract}

Kata kunci : Sistem Akuntansi Persediaan; Unit Pengendalian; PT. YYY.

\section{Analysis of Raw Material Inventory Accounting System in Controlling Inventory}

Abstract

The purpose of this study was to determine and explain the method of recording inventory, the application of the accounting system for raw material inventory, and inventory control carried out at pada PT. YYY In this study, the data obtained by the researcher used a qualitative descriptive method. This study uses primary data and secondary data where the data is carried out by direct research into the field and also uses library research.The results of the analysis show that found differences regarding the method used by the company with theory, the unit was in accordance with theory and no differences were found regarding the application of systems and procedures related to the inventory accounting system and related functions in the existing raw material inventory. theory and there are additional functions, namely warehouse functions, production, shipping and purchasing. However, there are multiple functions and there is often a mutation of goods without supporting documents and using only verbal at PT. $Y Y Y$.

Keywords : Inventory Accounting System; Control Unit; PT. YYY.

DOI: 10.25273 /inventory.v5vi2i.9911

Copyright (C) 2021 Penulis

Sume rights reserved. 


\section{Pendahuluan}

Dalam meningkatkan operasi perusahaan, salah satunya perusahaan harus memantau tingkat persediaan. Persediaan merupakan kunci pokok bagi perusahaan. Karena persediaan merupakan harta yang sangat penting untuk kelangsungan bisnis. Dalam iklim ekonomi yang kompetitif, sistem akuntansi persediaan merupakan alat perbaikan laba. Sistem persediaan yang lebih baik dapat meningkatkan profitabilitas, sementara sistem yang buruk dapat mengikis laba dan menjadi bsisnis kurang kompetitif.

Berdasarkan hasil wawancara dengan pencatat persediaan di PT. YYY Maret 2021 di PT YYY. Pencatatan persediaan bahan baku harus dilakukan dengan baik, karena dalam persediaan sering dijadikan objek manipulasi persediaan dengan demikian perusahaan diharapkan memiliki pengawasan yang memadai terhadap persediaan. Terjadinya selisih karena adanya komputer error dan kesalahan input oleh petugas (human error) sehingga harus melakukan pengecekan ulang pada saat stock opname. Kesalahan dalam pencatatan persediaan akan mempengaruhi neraca dan laba rugi yang mungkin terjadi hanya berpengaruh ataupun berpengaruh juga untuk kegiatan produksi selanjutnya. Sistem informasi antara pencatat persediaan yang kurang mengakibatkan kesalahan dalam pemasukan data.

Sistem persediaan merupakan kebijakan pengendalian untuk menentukan tingkat persediaan yang harus dijaga. Kekurangan persediaan (stockout) yang terjadi karena seringkali barang tidak dapat didatangkan secara mendadak dan sebesar yang dibutuhkan, yang menyebabkan terhentinya proses produksi, tertundanya penjualan, bahkan hilangnya pelanggan.Sistem akuntansi persediaan yang dimaksud adalah sistem akuntansi persediaan yang menyajikan informasi tentang persediaan karena untuk kelancaran kegiatan produksi, perusahaan memerlukan informasi yang tepat dan akurat tentang ketersediaan faktor produksi dalam jumlah, harga, serta mutu yang terjamin kontinuitasnya. Dengan adanya sistem akuntansi persediaan yang diterapkan dapat memberikan manfaat bagi pimpinan dan manajer perusahaan terutama dalam mengambil keputusan dan dalam menentukan langkah - langkah yang akan ditempuh oleh perusahaan terutama dalam melaksanakan aktivitas proses produksi agar berjalan dengan lancar. Sedangkan pengendalian persediaan, manajemen perusahaan dapat mengetahui sampai sejauh mana pelaksanaan efektivitas perusahaan telah tercapai, masalah- masalah yang ada dalam perusahaan, dan juga cara-cara mengatasi masalah tersebut.

Dalam setiap perusahaan pasti selalu ada kecurangan,kerusakan, dan kehilangan dalam persediaan bahan baku. Penggunaan sistem akuntansi persediaan dan pengendalian dalam pencatatan persediaan sangat dibutuhkan perusahaan. Dengan adanya pengendalian persediaan perusahaan dapat meminimalisir kecurangan, kerusakan dan kehilangan yang ada pada persediaan sehingga membuat pengelolaannya efektif dan efisien.

Berdasarkan latar belakang dan hasil wawancara yang diuraikan, peneliti tertarik untuk meneliti judul Analisis Sistem Akuntansi Persediaan Bahan Baku Dalam Mengendalikan Persediaan. Penulis memiliki tujuan dalam penelitian ini yaitu untuk mengetahui dan menjelaskan metode pencatatan persediaan,penerapan sistem akuntansi persediaan bahan baku dan pengendalian persediaan yang dilakukan PT. YYY.

\section{Metode Penelitian}

Metode yang digunakan dalam penelitian ini adalah metode penelitian kualitatif yang berdasarkan data. Dalam penelitian ini menggunakan data sekunder. Menurut Sugiyono (2018:376) Data sekunder merupakan sumber yang tidak langsung memberikan data kepada pengumpul data. Data sekunder dalam penelitian ini merupakan data - data yang diperoleh dari 
bahan - bahan kepustakaan, dokumen-dokumen atau arsip lainnya yang diterima dari pihak PT. YYY. Penulis mengamati secara langsung aktivitas, orang - orang yang berada di lingkungan PT. YYY dalam penelitian ini,. Sampel dalam penelitian kualitatif juga bukan merupakan sampel statistik tetapi sampel teoritis karena tujuan penelitian kualitatif merupakan untuk menghasilkan teori. Penulis melakukan observasi dan wawancara kepada orang yang dipandang mengetahui tentang situasi sosial tersebut dalam penelitian ini.

\section{Hasil dan Pembahasan}

\section{Analisis Metode Pencatatan Persediaan Pada PT. YYY}

Menurut Dwi Martani, Sylvia, Ratna, Aria dan Edward (2016:250), dalam melakukan pencatatan persediaan, teknis pencatatan persediaan tekait juga sistem pencatatan persediaan yang digunakan oleh entitas. Entitas dapat menggunakan sistem periodik atau sistem perpektual

a. Sistem periodik merupakan sistem pencatatan persediaan di mana kuantitas persediaan ditentukan secara periodik yaitu hanya saat perhitungan fisik yang biasanya dilakukan secara stock opname.

b. Sistem perpetual merupakan sistem pencatatan persediaan dimana pencatatan yang up-to-date terhadap barang persediaan selalu dilakukan setiap terjadinya nilai persediaan.

Pada analisis ini metode yang digunakan dalam melakukan pencatatan persediaan terutama dalam proses pencatatan persediaan hasil produksi pada PT. YYY adalah metode mutasi persediaan atau metode perpetual. Dimana setiap kali adanya mutasi keluar masuknya persediaan selalu dicatat secara manual maupun komputer secara rinci. Ada dua pencatatan persediaan yang ada dilakukan secara manual dan komputer. Pencatatan manual ada pada buku persediaan sedangkan komputer menggunakan sistem Enterprise Resource Planning (ERP) dengan cara scan barcode.Bagian gudang bertanggung jawab atas barang yang ada digudang.Penggunaan metode mutasi dan metode persediaan fisik yang diterapkan dalam persediaan bahan baku pada PT. YYY menggunakan metode masuk pertama keluar pertama (MPKP). Dimulai dari prosedur penerimaan barang sampai perhitungan fisik persediaan yang dilakukan setiap akhir bulan. Pemilihan metode ini cukup baik karena barang yang masuk gudang awal akan dikeluarkan lebih dulu, hal ini dapat mengurangi resiko adanya barang yang rusak karena terlalu lama dalam penyimpanan dan menghindari barang yang mengalami penurunan kualitas. Analisis Sistem Dan Prosedur Yang Terkait Dengan Sistem Akuntansi Persediaan Pada PT. YYY

Menuurut Mulyadi (2016:463) Sistem akuntansi persediaan bertujuan untuk mencatat mutasi setiap jenis persediaan yang ada digudang.

Menuurut Mulyadi (2016:463) Ada beberapa sistem dan prosedur yang berkaitan dengan sistem akuntansi persediaan yaitu sebagai berikut :

1. Prosedur pencatatan produk jadi

2. Prosedur pencatatan harga pokok produk jadi yang dijual

3. Prosedur pencatatan harga pokok produk jadi yang diterima kembali dari pembeli

4. Prosedur pencatatan tambahan dan penyesuaian kembali harga pokok persediaan produk dalam proses

5. Prosedur pencatatan harga pokok persediaan yang dibeli

6. Prosedur pencatatan harga pokok persediaan yang dikembalikan kepada pemasok

7. Prosedur permintaan dan pengeluaran barang gudang

8. Prosedur pencatatan tambahan harga pokok persediaan karena pengembalian barang gudang 
9. Sistem penghitungan fisik

Hasil Penelitian sistem akuntansi persediaan yang digunakan PT. YYY sudah menggunakan sistem khusus namun juga masih memakai sistem manual, menurut hasil wawancara dengan karyawan PT. YYY hal ini dilakukan agar persediaan dapat lebih terkontrol, mengingat terkadang adanya selisih antara catatan pada program dengan barang yang ada. PT. YYY telah menerapkan sistem akuntansi persediaan bahan baku sebagai berikut :

Prosedur Pencatatan Produk Jadi

Prosedur pencatatan produk jadi di dapat hasil analisis sebagai berikut :

a. Bagian produksi menginput dan membuat laporan produk selesai, diberikan kepada bagian gudang dan PPIC dengan sebuah form produksi.

b. Bagian gudang menerima laporan produk selesai dan menghitungnya lalu gudang mengisi kartu persediaan. Dalam kartu persediaan terjadi adanya penambahan persediaan.

c. Bagian gudang menerima laporan produk selesai dan mencatanya lalu gudang mengisi kartu persediaan.

d. Bagian gudang memberikan laporan produk selesai pada bagian accounting.

e. Bagian accounting mencatat dan membuat jurnal produk selesai.

Kendala yang dihadapi pada prosedur ini, komputer sering error pada saat input pada sistem. Namun bisa dihadapi dengan diperbaiki oleh tim IT.

Prosedur Pencatatan Produk Jadi Yang Dijual

Prosedur pencatatan produk jadi yang dijual di dapat hasil analisis sebagai berikut :

a. Bagian gudang menerima surat order pengiriman dari bagian market order dan mencatatnya pada kartu persediaan.

b. Bagian market shipping menerima berkas dan melakukan pengecekan berkas apakah barang dan berkas sudah sesuai, setelah sudah sesuai barang dimasukan kedalam container dan melakukan pengiriman atau ekspor.

c. Bagian accounting menerima laporan produk yang dijual, mencatat danmembuat jurnal.

Kendala yang dihadapi pada prosedur ini ketika pada saat pengecekan barangsering terjadinya perbedaan berkas dan barang.

Prosedur Pencatatan Persediaan yang Dikembalikan dari Pembeli

Prosedur pencatatan persediaan yang dikembalikan dari pembeli dapat hasil analisis sebagai berikut :

a. Bagian PPIC menerima barang dan melakukan pengecekan barang, lalu membuat laporan peneriman barang dan kartu persediaan.

b. Bagian gudang menerima dan membuat laporan penerimaan barang, mengecek barang dan menyimpan barang, serta ngisi kartu persediaan. Terjadinya penambahan dalam persediaan karena pembelimengembalikannya.

c. Bagian accounting menerima laporan penerimaan barang, mencatat penambahan produk dan menjurnalnya.

Pada prosedur ini bagian purchasing merangkap dua fungsi yaitu fungsi penerimaan dan pembelian.

\section{Prosedur Pencatatan Persediaan Produk dalam Proses}

Prosedur pencatatan persediaan produk dalam proses di dapat hasil analisissebagai berikut : 
a. Bagian produksi membuat laporan produk dalam proses dan memberikanpada bagian PPIC.

b. Bagian PPIC mencatat dan mengisi kartu persediaan dan memberikan padabagian accounting.

c. Bagian accounting mencatat dan membuat jurnal persediaan dalam proses.

\section{Prosedur Pencatatan Persediaan Yang Dibeli}

Prosedur pencatatan persediaan produk yang dibeli dalam proses di dapat hasil analisis sebagai berikut :

a. Terjadinya purchase order pada bagian marketing order, marketing order memberi tahu bagian gudang dan PPIC.

b. Bagian gudang

a) Pada saat adanya order

Bagian gudang melakukan pengecekan persediaan. Apabila persediaan masih ada melakukan pengiriman pada bagian produksi dan apabila persediaan tidakada bagian gudang mebuat laporan kepada bagian PPIC untuk melakukan pembelian dengan mengisi form MR.

b) Pada saat barang datang

Bagian gudang melakukan pengecekan persediaan dan mengisi kartu persediaan.

c. Bagian PPIC

a) Menerima form MR dari gudang

b) Pagian PPIC melakukan PO

Bagian PPIC melakukan pengecekan barang, jika barang sesuai akan segera masuk pada bagian gudang jika tidak sesuai akan dilakukan retur.

d. Bagian accounting menerima laporan penerimaan barang dan membuat jurnal.

Kendala dalam prosedur ini adalah bagian marketing memberitahu hanya lewat lisan tidak dengan secara tertulis yang mengakibatkan jika adanya keselahan tidak ada bukti tertulis, dan adanya perangkapan fungsi pada prosedur ini yaitu bagian penerimaan dan pemesan dilakukan oleh bagian PPIC.

Prosedur Pencatatan Persediaan Yang Dikembalikan Kepada Pemasok

Prosedur pencatatan persediaan yang dikembalikan kepada pemasok dalam proses di dapat hasil analisis sebagai berikut:

a. Bagian gudang mempersiapkan barang yang akan diretur dan memberitahu bagian PPIC secara lisan. Jika persediaan yang dibutuhkan sangat mendesak akan menggunakan form bukti transfer barang selesai atau material request (MR).

b. Bagian PPIC Menerima laporan barang yang akan diretur dan mengisi dalamkartu persediaan serta melakukan retur.

c. Bagian accounting menerima laporan dan mencatatnya serta membuat jurnal.

\section{Prosedur Permintaan dan Pengeluaran Persediaan Gudang}

Prosedur pencatatan permintaan dan pengeluaran barang gudang di dapathasil analisis sebagai berikut:

a. Bagian produksi menerima pemberitahuan dari marketing bahwa ada purchase order, setelah mendapat pemberitahuan bagian produksi membuat permintaan dengan membuat Surat Perintah Kerja (SPK) pada bagian gudang.

b. Bagian gudang menerima surat perintah kerja dan melakukan pengecekan pada persediaan bahan baku akan mengecek persediaan bahan baku, apabilabahan baku tidak mencukupi untuk produksi maka akan meminta PPIC untuk membeli bahan 
baku. Apabila bahan baku yang tersedia digudang mencukupiuntuk proses produksi maka melakukan pengiriman bahan baku. Bagian gudang hanya menginput dengan scan barcode tidak membuat bukti pengeluaran barang yaitu dokumen pendukung yang seharusnya menggunakan dokumen pendukung.

c. Bagian acconting mencatat persediaan dan membuat jurnal.

Bagian gudang sering hanya menginput dengan scan barcode tidak membuatbukti pengeluaran barang yaitu dokumen pendukung yang membuat adanya resiko.

\section{Prosedur Pengembalian Barang Gudang}

Prosedur pengembalian barang gudang di dapat hasil analisis sebagai berikut:

a. Saat barang datang bagian produksi mengecek barang jika ada barang yang tidak sesuai maka bagian produksi akan menghubungi gudang dan melakukanretur. Sering terjadi bagian produksi meminta barang tanpa form yang hanyamenggunakan lisan. Bagian produksi menggunakan form hanya untuk permintaan mendesak.

b. Bagian gudang menerima laporan dari bagian produksi dan melakukan retur serta mengisi kartu persediaan. Selanjutnya operator gudang tersebut harus mencatat kuantitas barang yang diterima kembali oleh gudang material, dan admin gudang material melakukan input di sistem navision.

c. Bagian accounting pencatatan dan membuat jurnal.

\section{Sistem Stock Opname}

a. Bagian gudang menerima kartu stock opname yang selanjutnya melakukan perhitungan serta mengisi kartu stock opname . setelah selesai melakukan stock opname bagian gudang menyerahkan pada bagian PPIC.

b. Bagian PPIC menerima kartu stock opname yang selanjutnya melakukan perbandingan jika perbandingan cocok dilakukan prosedur kompilasi namun jika sebaliknya melakukan perhitungan ulang.

Kendala saat perhitungan fisik adalah ketika saat adanya selisih karena dalam mencari selisih membutuhkan waktu tertentu.

\section{Analisis Pengendalian Persediaan Bahan Baku}

Menurut Cenik Ardana dan Hendro Lukman (2016:14) Dilihat dari proses bekerjanya unit pengendalian maka dibedakan beberapa tipe proses pengendaliannya, yaitu:

1. Proses pengendalian umpan balik (feeback control),

2. Proses pengendalian umpan maju (feed forward control)

3. Proses pengendalian pencegahan (preventif control)

4. Proses pengendalian kotak hitam (black box control)

Dari proses bekerjanya unit pengendalian maka ada beberapa tipe proses

pengendaliannya yang ada pada PT. YYY :

Proses Pengendalian Umpan Balik

Perusahaan menetapkan suatu target produksi dalam suatu line yang keluaradalah 924 pcs perhari. Kemudian team leader atau grup leader (team pengendali) pada suatu line akan mengevaluasi hasil kerja selama satu hari dengan menjalankan proses produksi. Setelah mengevaluasi ternyata target yang didapatkan hanya 840 pcs pasang perhari. Unit pengendali kondisi rill target dengan dengan standar minimal kemudian berkesimpulan target yang diharapkan masih dibawah batas toleransi. Atas dasar ini makan unit pengendali melakukan evaluasi atas masukan, misalnya proses seleksi calon karyawan, pengecekan SOP (Standar Oprasional Kerja) karena pada saat melakukan tanggung jawabnya sering terjadi karyawan tidak melakukan prosedur sesuai SOP , mengecek mesin, menghindari barang yang reject dan lain sebagainya) untuk menyempurnakan proses produksi. 


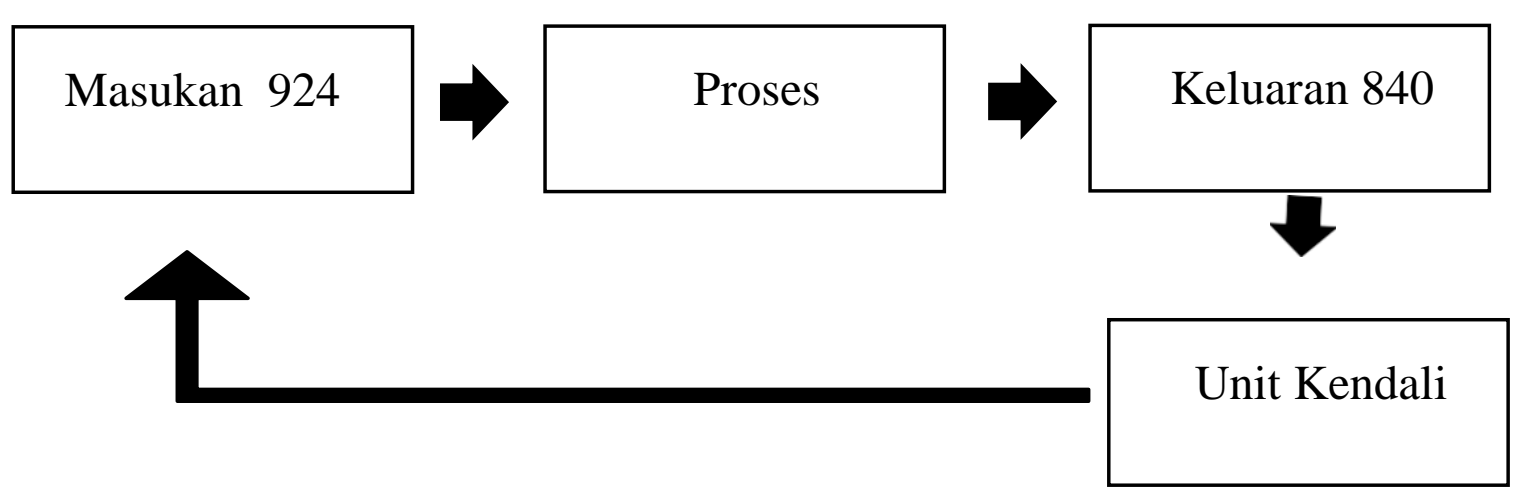

Gambar 1 Proses Pengendalian Umpan Balik

Sumber : Diolah oleh penulis 2021 PT. YYY

\section{Proses Pengendalian Umpan Maju}

Dalam perusahaan ini selalu diadakannya audit. Dalam pengendalian umpan maju selalu diadakannya audit pada bagian persediaan audit dilakukan bertujuan untuk mengetahui apakah permintaan dan pengluaran barang dari gudang selalu sesuai dengan SOP. Pada pengendaliaan atas persediaan apakah SOP dijalankan pada persediaan apa bila tidak team audit akan memberi arahan pada saat audit. Proses dalam permintaan dan pengeluaran bahan baku sering kali tidak sesuai SOPterkadang hanya menggunakan lisan tanpa menggunakan dokumen pendukung. Resikonya akan ada selisih pada saat stock opname jika adanya kesalahan input pada sistem dan tidak ada bukti dokumen.

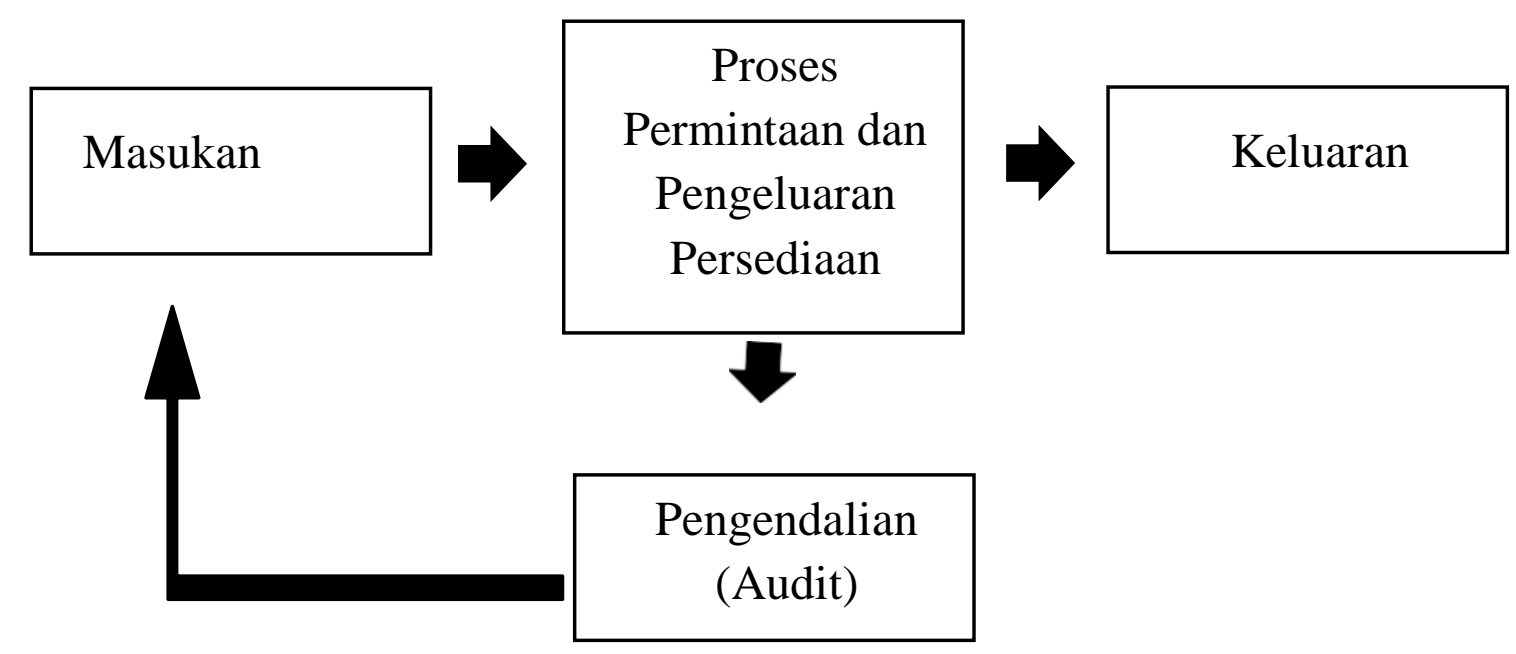

\section{Gambar 2 Proses Pengendalian Umpan Maju \\ Sumber : Diolah oleh penulis 2021 PT. YYY}

\section{Proses Pengendalian Pencegahan}

Unit pengendalian adalah PPIC yaitu purchasing pada saat adanya barang datang purchasing akan melakukan pengecekan pada barang dan dokumen untuk memastikan kesesuaiannya. 
Bila kualitas bahan baku yang diterima telah sesuai dengan apa yang telah di pesan maka kualitas produksi akan baik.

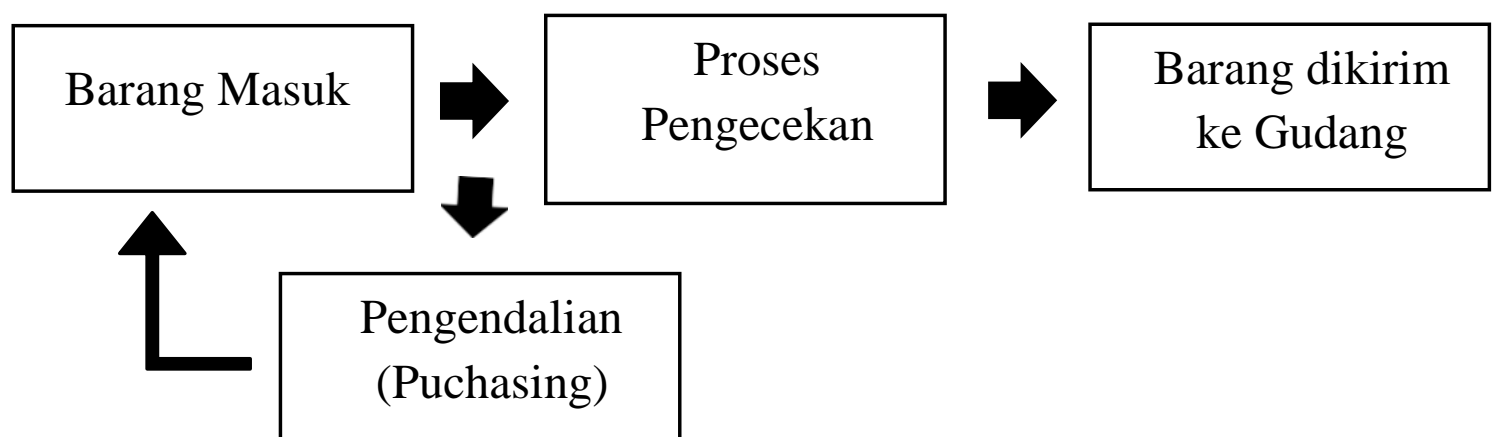

Gambar 3 Proses Pengendalian Pencegahan

Sumber : Diolah oleh penulis 2021 PT. YYY

\section{Proses Pengendalian Kotak Hitam}

Dalam unit pengendalian ini mempelajari pola hubungan antara masukan dengan keluaran tanpa melakukan pengawasan terhadap prosesnya. Tipe pengendalian kotak hitam ini dipilih terhadap sistem jika proses yang terjadi di dalam sistem tersebut sangat sulit untuk diketahui, atau kalaupun ingin mengetahui prosesnya, biaya yang ditimbulkan akan lebih besar dari manfaatnya. Contohnya pada saat dilakukannya perhitungan fisik ada selisih dalam perhitungan.

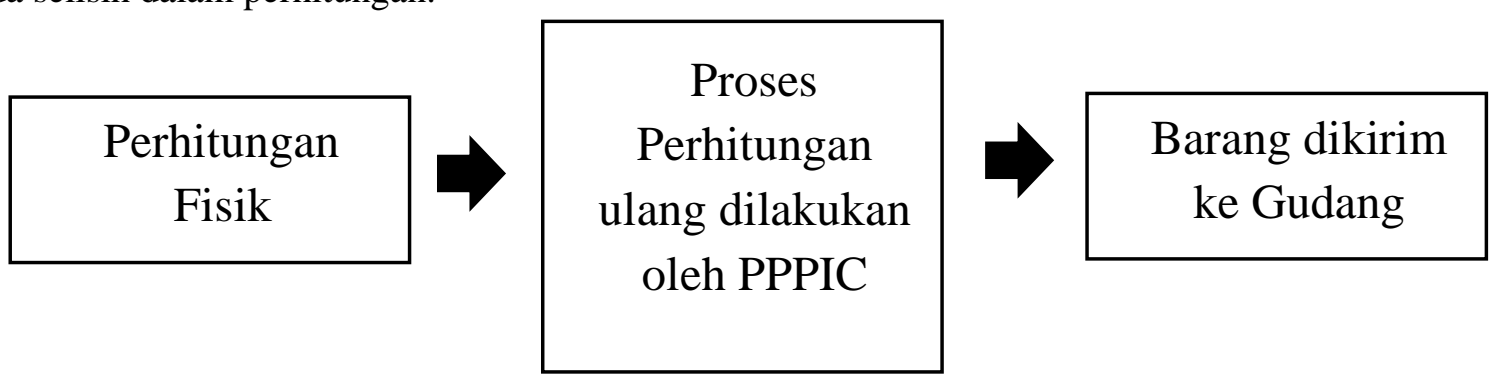

Gambar 4 Proses Pengendalian Kotak Hitam

Sumber : Diolah oleh penulis 2021 PT. YYY

\section{Kesimpulan}

Berdasarkan penelitian yang dilakukan penulis pada produksi PT. YYY, maka dapat ditarik kesimpulan bahwa tidak ditemukan adanya perbedaan dengan teori :

1) Sistem pencatatan persediaan yang dimana setiap kali adanya mutasi keluar masuknya persediaan selalu dicatat secara manual maupun komputer secara rinci di PT. YYY

2) Mengenai penerapan sistem dan prosedur yang terkait dengan sistem akuntansi persediaan di PT. YYY. Namun dalam mengendalikan adanya perangkapan fungsi oleh karyawan misalnya fungsi purchasing melakukan dua fungsi.Sering terjadi bagian produksi meminta barang tanpa form yang hanya menggunakan lisan, bagian produksi menggunakan form hanya untuk permintaan mendesak. Bagian gudang hanya menginput dengan scan barcode tidak membuat bukti pengeluaran barang yaitu dokumen pendukung. Hal ini dalam melakukan pencatatan persediaan, perusahaan harus lebih memperhatikan kelengkapan 
dokumen yang berkaitan dengan persediaan hasil produksi sendiri serta persediaan agar tidak terjadi hambatan dalam pelaksanaan pencatatan persediaannya. Karena dengan adanya dokumen pedukung dapat meminimalisir jika adanya human error, selisih sering terjadi adanya human error.

3) Bekerjanya unit pengendalian pada PT. YYY sudah sesuai teori. Yaitu ada empat proses pengendalian proses pengendalian umpan balik, roses pengendalian umpan maju, Proses pengendalian pencegahan, dan Proses pengendalian kotak hitam.

\section{Daftar Pustaka}

Ardana,Cenik dan Hendro Lukman.(2016). Sistem Informasi Akuntansi. Jakarta: Mitra Wacana Media

Martani,Dwi. Syilvia Veronica Siregar, Ratna Wardhani, Aria Farahmita and Edward Tanujaya.(2016).Akuntansi Keuangan Menengah Berbasi PSAK.Jakarta Selatan:Salemba Empat

Mulyadi. (2016). Sistem Akuntansi. Jakarta Selatan :Salemba Empat Sugiyono. (2018) . Metode Penelitian Manajemen.Bandung:Alfabeta 